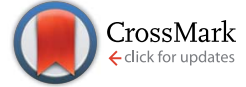

Cite this: RSC Adv., 2016, 6, 102549
Received 15th September 2016 Accepted 12th October 2016

DOI: $10.1039 / c 6 r a 23082 b$

www.rsc.org/advances

\section{The synthesis and electrical properties of hybrid gel electrolytes derived from Keggin-type heteropoly acids and 3-(pyridin-1-ium-1-yl)propane-1- sulfonate (PyPs) $\uparrow$}

\begin{abstract}
Sumaletha Narayanan, Xia Tong and Venkataraman Thangadurai*
Herein, we report the effect of the proton concentration in polyoxometalates (POMs) upon hybrid formation with ionic liquids (ILs), and their ionic conductivity relationship to optimize their ionic conductivity. The hybrid gels were derived from Keggin-type heteropoly acids containing different proton concentrations, such as $\mathrm{H}_{3} \mathrm{PW}_{11} \mathrm{MoO}_{40}, \mathrm{H}_{4} \mathrm{PMO}_{11} \mathrm{VO}_{40}$ and $\mathrm{H}_{5} \mathrm{PMO}_{10} \mathrm{~V}_{2} \mathrm{O}_{40}$, and 3-(pyridin-1-ium1-yl)propane-1-sulfonate (PyPs) IL. Elemental $\mathrm{C}, \mathrm{H}$, and $\mathrm{N}$ analysis was found to be consistent with the theoretical composition within $4 \%$ for $\mathrm{C}$ and $\mathrm{N}$, whereas $\mathrm{H}$ content was found to be slightly higher than the anticipated value, which may be due to potential uptake of water during the sample preparation. ${ }^{1} \mathrm{H}$ and ${ }^{13} \mathrm{C}$ nuclear magnetic resonance and Fourier transform infrared spectroscopy (FTIR) confirmed the presence of functional groups of PyPs in the hybrids. In situ variable temperature powder X-ray diffraction (PXRD), thermogravimetric analysis (TGA), electrochemical AC impedance spectroscopy and cyclic voltammetry studies showed excellent thermal (up to $\sim 300{ }^{\circ} \mathrm{C}$ ) and electrochemical ( $3 \mathrm{~V}$ at room temperature) stability of $[\mathrm{PyPs}]_{3} \mathrm{PW}_{11} \mathrm{MoO}_{40}$. The structural characterizations confirmed the interaction between the organic cation and Keggin-type inorganic heteropoly anion in the hybrid material. The bulk ionic conductivity of $0.1,0.01$ and $0.0003 \mathrm{~S} \mathrm{~cm}^{-1}$ at $\sim 90{ }^{\circ} \mathrm{C}$ was obtained for $[\mathrm{PyPs}]_{3} \mathrm{PW}_{11} \mathrm{MoO}_{40}$, $[\mathrm{PyPs}]_{4} \mathrm{PMO}_{11} \mathrm{VO}_{40}$ and $[\mathrm{PyPs}]_{5} \mathrm{PMO}_{10} \mathrm{~V}_{2} \mathrm{O}_{40}$, respectively.
\end{abstract}

\section{Introduction}

A lot of effort has been made recently to prepare hierarchical structured materials for alternative electrochemical energy storage (e.g., for batteries and capacitors) and conversion (e.g., for fuel cells) technologies. ${ }^{1-3}$ These hierarchical materials are prepared by soft-chemical synthesis methods and they exhibit superior physical and chemical properties..$^{1-6}$ For example, a nanosheet array of $\mathrm{NiMoO}_{4}$ prepared by a hydrothermal method showed a specific capacity of $1483 \mathrm{Fg}^{-1}$ and a nanopyramid array of metallic $\mathrm{CoS}_{2}$ synthesized by a one-step solvothermal method showed a low over-potential of $0.14 \mathrm{~V}$ for $\mathrm{H}_{2}$ evolution under acidic conditions. ${ }^{4,5}$ Hybrid polyoxometalates (POMs) and ionic liquids (ILs) have drawn wide attention in material research due to their applications in catalysis, medicine, and electrochemical energy conversion and storage devices. ${ }^{7-12}$ POMs are anionic metal oxides derived from transition metal oxides, which have a robust structure and exhibit very useful functional physical and chemical properties,

Department of Chemistry, University of Calgary, 2500 University Drive NW, Calgary, Alberta, T2N 1N4 Canada. E-mail: vthangad@ucalgary.ca; Tel: +1 4032108649

$\dagger$ Electronic supplementary information (ESI) available. See DOI: $10.1039 / \mathrm{c} 6 \mathrm{ra} 23082 \mathrm{~b}$ including electrical, magnetic, electrochemical and photonic properties. ${ }^{13}$ ILs are low melting point salts, which are typically comprised of organic cations and inorganic or organic anions possessing very low vapour pressure, non-flammability, high ionic conductivity, and high chemical, thermal and electrochemical stability windows. ${ }^{14-16}$ These unique properties of POMs and ILs are combined in their respective hybrid compounds, which ensure the tunability of desired physical and chemical properties by varying the transition metal cations in the former case, and organic cations and anions in the latter case. The POM-based IL salts offer several advantages, such as being solvent-free, possessing residual acidity and good thermal stability, and having much higher ionic conductivity than the corresponding anhydrous solid analogues. They also exhibit a low vapor pressure, which is beneficial for hightemperature (above $100{ }^{\circ} \mathrm{C}$ ) fuel cells and catalytic applications. The commonly used organic cations are substituted imidazolium, pyridinium, pyrrolidinium, and alkyl ammonium and phosphonium cations, and anions include tetrafluoroborate, hexafluorophosphates and bis(trifluoromethanesulfonyl)imide. ${ }^{17-21}$ Various hybrid gels were developed using POMs and ILs such as $N$ methyl imidazolium-1-(3-sulfonic group) propyl (MIMPS), 3(pyridine-1-ium-1-yl)propane-1-sulfonate (PyPs), 1-(3-sulfonic group) triethylamine (TEAPS) and $N$-propyl- $N$-methylpiperidinium 
hexafluorophosphate. ${ }^{2-30}$ Several heteropoly acids (HPAs) and polyvinylpyrrolidone (PVP) and polyethylene glycol (PEG) hybrids were also recently reported. ${ }^{28}$

Herein, we report the synthesis and structural, chemical and electrochemical characterization of hybrid gel electrolytes based on recently developed 3-(pyridin-1-ium-1-yl)propane-1sulfonate (PyPs) ${ }^{24} \mathrm{IL}$ and $\mathrm{H}_{3} \mathrm{PW}_{11} \mathrm{MoO}_{40}, \mathrm{H}_{4} \mathrm{PMo}_{11} \mathrm{VO}_{40}$ and $\mathrm{H}_{5} \mathrm{PMo}_{11} \mathrm{~V}_{2} \mathrm{O}_{40}$ for potential electrochemical energy conversion and storage applications. The investigated POMs-ILs hybrid materials were found to be thermally stable to about $300{ }^{\circ} \mathrm{C}$. Hybrid $[\mathrm{PyPs}]_{3} \mathrm{PW}_{11} \mathrm{MoO}_{40}$ showed the highest electrical conductivity of $0.1 \mathrm{~S} \mathrm{~cm}^{-1}$ at $\sim 90{ }^{\circ} \mathrm{C}$ in ambient conditions, which is comparable to the proton conductivity of Nafion under high relative humidity, and an electrochemical stability window of $\sim 3 \mathrm{~V}$ at room temperature.

\section{Experimental}

\subsection{Synthesis of solid acid $\mathrm{H}_{3} \mathrm{PW}_{11} \mathrm{MoO}_{40}\left(\mathrm{H}_{3} \mathrm{PWMo}\right)$}

Heteropoly acid (HPA) or polyoxometalate (POM) of the nominal chemical composition $\mathrm{H}_{3} \mathrm{PW}_{11} \mathrm{MoO}_{40}$ was synthesized according to a literature method. ${ }^{22} \mathrm{Na}_{2} \mathrm{MoO}_{4}$ (0.01 mol) (BDH, 99.5\%) was dissolved in $20 \mathrm{ml}$ of deionized water. $\mathrm{Na}_{2} \mathrm{WO}_{4} \cdot 2 \mathrm{H}_{2} \mathrm{O}(0.1$ mol) (Sigma Aldrich, 99\%) was mixed with 0.02 mol of $\mathrm{Na}_{3}$ $\mathrm{PO}_{4} \cdot 12 \mathrm{H}_{2} \mathrm{O}$ (Fisher Scientific, $100 \%$ ) and dissolved in $100 \mathrm{ml}$ of deionized water and was added to the sodium molybdate solution. Dilute $\mathrm{H}_{2} \mathrm{SO}_{4}(1: 1)$ was used to adjust $\mathrm{pH}$ of the mixture to $\sim 2.5$ and was then heated at $90{ }^{\circ} \mathrm{C}$ for $2 \mathrm{~h}$. It was allowed to cool down to room temperature and the solution was extracted using ether $(50 \mathrm{ml})$ and dilute $\mathrm{H}_{2} \mathrm{SO}_{4}(1: 1)$ prior to drying in a vacuum oven at $50{ }^{\circ} \mathrm{C}$ for $24 \mathrm{~h}$ to obtain the solid product.

\subsection{Synthesis of solid acid $\mathrm{H}_{4} \mathrm{PMo}_{11} \mathrm{VO}_{40}\left(\mathrm{H}_{4} \mathrm{PMoV}\right)$}

$0.01 \mathrm{~mol}$ of $\mathrm{NaVO}_{3}$ (BDH, 98\%) was dissolved in $20 \mathrm{ml}$ of deionized water. $80 \mathrm{ml}$ of $\mathrm{Na}_{2} \mathrm{MoO}_{4}(0.1 \mathrm{~mol})(\mathrm{BDH}, 99.5 \%)$ was mixed with $20 \mathrm{ml}$ of $\mathrm{Na}_{3} \mathrm{PO}_{4} \cdot 12 \mathrm{H}_{2} \mathrm{O}(0.01 \mathrm{~mol})$ (Fisher Scientific, $100 \%)$ solution. The rest of the steps were the same as mentioned for the $\mathrm{H}_{3}$ PWMo synthesis.

\subsection{Synthesis of solid acid $\mathrm{H}_{5} \mathrm{PMo}_{10} \mathrm{~V}_{2} \mathrm{O}_{40}\left(\mathrm{H}_{5} \mathrm{PMoV}\right)$}

$0.02 \mathrm{~mol}$ of $\mathrm{NaVO}_{3}$ (BDH, 98\%) was dissolved in $20 \mathrm{ml}$ of deionized water. $\mathrm{Na}_{2} \mathrm{MoO}_{4}(0.01 \mathrm{~mol})(\mathrm{BDH}, 99.5 \%)$ was mixed with $0.01 \mathrm{~mol}$ of $\mathrm{Na}_{3} \mathrm{PO}_{4} \cdot 12 \mathrm{H}_{2} \mathrm{O}$ (Fisher Scientific, $100 \%$ ) and dissolved in $100 \mathrm{ml}$ of deionized water. The rest of the steps were the same as mentioned for $\mathrm{H}_{3}$ PWMo synthesis.

\subsection{Synthesis of PyPs ionic liquid}

Synthesis of ionic liquid, 3-(pyridine-1-ium-1-yl)propane-1sulfonate (PyPs) was carried out as per a procedure reported elsewhere. ${ }^{29}$ As received, $4.4 \mathrm{ml}$ of 1,2-oxathiolane 2,2-dioxide (Alfa Aesar, 99\%) was added to $50 \mathrm{ml}$ of acetone. $4.0 \mathrm{ml}$ pyridine (Alfa Aesar, 99\%) was added to this solution followed by continuous heating at $50{ }^{\circ} \mathrm{C}$ for $4 \mathrm{~h}$ with stirring. A white precipitate was formed which was filtered, washed with ether and dried in vacuum.

\subsection{Synthesis of hybrid gels}

PyPs (3-(pyridine-1-ium-1-yl)propane-1-sulfonate) and POM hybrid gel electrolytes were synthesized by taking $3: 1,4: 1$, and $5: 1$ mole ratios of PyPs and $\mathrm{H}_{3} \mathrm{PW}_{11} \mathrm{MoO}_{40}, \mathrm{H}_{4} \mathrm{PMo}_{11} \mathrm{VO}_{40}$, and $\mathrm{H}_{5} \mathrm{PMo}_{10} \mathrm{~V}_{2} \mathrm{O}_{40}$, respectively. PyPs was added to an aqueous solution of the heteropoly acids, $\mathrm{H}_{3} \mathrm{PW}_{11} \mathrm{MoO}_{40}, \mathrm{H}_{4} \mathrm{PMo}_{11} \mathrm{VO}_{40}$, and $\mathrm{H}_{5} \mathrm{PMo}_{11} \mathrm{VO}_{40}$ with constant stirring for overnight at room temperature. Water was removed from the solution by vacuum drying to get the desired hybrid gel products $[\mathrm{PyPs}]_{3} \mathrm{PW}_{11} \mathrm{MoO}_{40}$ (PyPs- $\left.\mathrm{H}_{3} \mathrm{PWMo}\right), \quad[\mathrm{PyPs}]_{4} \mathrm{PMo}_{11} \mathrm{VO}_{40} \quad\left(\mathrm{PyPs}-\mathrm{H}_{4} \mathrm{PMoV}\right)$ and [PyPs $]_{5} \mathrm{PMo}_{10} \mathrm{~V}_{2} \mathrm{O}_{40}$ (PyPs- $\left.\mathrm{H}_{5} \mathrm{PMoV}\right)$. Schematic of the formation of hybrid gel electrolytes starting from PyPs and POMs is shown in Scheme 1.

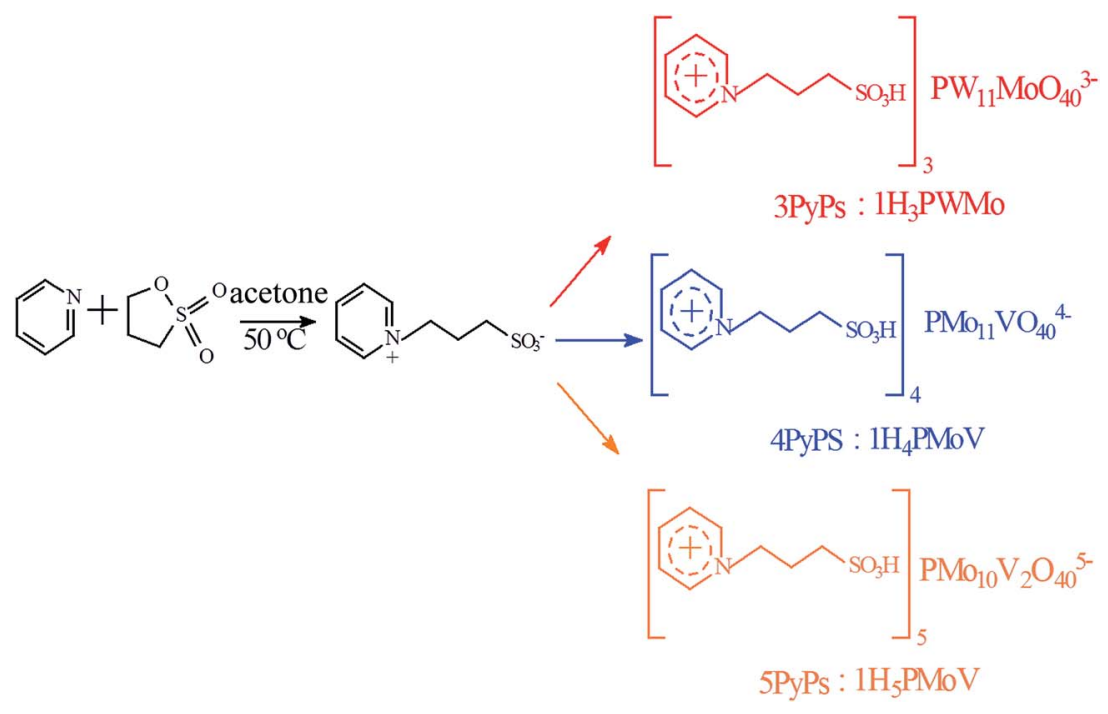

Scheme 1 Synthesis of POMs-based IL hybrid gel electrolytes. 


\subsection{Characterization}

A PerkinElmer Series II C H N S/O Analyzer 2400 was used for the CHN analysis to understand the composition of PyPs and PyPsPOM hybrids. The purity of these compounds was checked by employing ${ }^{1} \mathrm{H}$ and ${ }^{13} \mathrm{C}$ NMR (nuclear magnetic resonance) (Bruker RDQ 400 NMR spectrometer) spectroscopy. The Fourier transform infrared spectra of the samples were recorded by employing a Varian 7000 FTIR spectrometer in the 600-2000 $\mathrm{cm}^{-1}$ range using $\mathrm{KBr}$ standard. The structural analysis was carried out using powder X-ray diffraction (PXRD) and a Bruker D8 Advance powder X-ray diffractometer ( $\mathrm{Cu}-\mathrm{K} \alpha$ radiation; $40 \mathrm{~mA}$; $40 \mathrm{kV}$ ) was used for this purpose. The scanning was carried out at a $0.02^{\circ} \mathrm{s}^{-1}$ rate from $2 \theta=2$ to $40^{\circ}$ at room temperature. The variable temperature $\left(30-120{ }^{\circ} \mathrm{C}\right)$ PXRD was also done using an Anton Par XRK 900 high temperature reactor chamber. The samples were held for 30 minutes at each temperature to ensure thermal equilibrium. A thermogravimetric analyzer (Setaram TAG 16 TGA/DSC dual chamber balance) was used to study the thermal stability of the samples under $\mathrm{N}_{2}$ gas up to $650{ }^{\circ} \mathrm{C}$ at a $10{ }^{\circ} \mathrm{C} \mathrm{min}^{-1}$ heating rate. The electrical conductivity measurements were done using a Solartron SI 1260 impedance and gainphase analyzer in the frequency range of $0.01 \mathrm{~Hz}$ to $1 \mathrm{MHz}$ (AC amplitude $100 \mathrm{mV}$ ) in air by heating the sample from room temperature to $100{ }^{\circ} \mathrm{C}$. A VersaSTAT 3 potentiostat was employed for the cyclic voltammetry using a 3-electrode sample set up under $\mathrm{N}_{2}$ atmosphere. Pt electrodes were used as the working (WE) and counter electrodes (CE), and $\mathrm{Ag} / \mathrm{AgCl}$ was used as the reference electrode (RE). ${ }^{16}$

\section{Results and discussion}

\subsection{Phase analysis}

Fig. $\mathrm{S} 1 \uparrow$ shows the photographs of heteropoly acid, $\mathrm{H}_{4} \mathrm{PMo}_{11} \mathrm{VO}_{40}$ and its derivative hybrid $\mathrm{PyPs}-\mathrm{H}_{4} \mathrm{PMoV}$ compound at room temperature. The freshly made product was a dark green transparent semisolid at room temperature. $\mathrm{PyPs}-\mathrm{H}_{4} \mathrm{PMoV}$ turned to liquid by heating it to nearly $80{ }^{\circ} \mathrm{C}$ where it exhibited thermotropic liquid crystal behaviour. The melting point of the hybrid compounds can be related to the coulombic attraction $\left(E_{\mathrm{c}}\right)$ between the constituent ions, and is described by eqn (1):

$$
E_{\mathrm{c}}=\frac{M Z^{+} Z^{-}}{r^{2}}
$$

where $M$ is the Coulomb's law constant, $Z^{+}$and $Z^{-}$are signed magnitudes of cations and anions charges, and $r$ is the interionic separation. For larger ions possessing lower ionic charge, the formation of low melting salts is favoured. This is because the larger size enables the effective delocalization of the charge as well as enhances the charge separation. Rickert et al. proposed that the ionic salts made from a polyoxometalate anion and an organic cation will have a lower melting point when the POM has a lower charge. ${ }^{30}$

\subsection{Composition analysis}

CHN analysis results of the as-prepared PyPs (IL), and all its hybrid compounds, PyPs- $\mathrm{H}_{3} \mathrm{PWMo}$, PyPs- $\mathrm{H}_{4} \mathrm{PMoV}$, and PyPs$\mathrm{H}_{5} \mathrm{PMoV}$ are summarized in Table $\mathrm{S} 1$ (see the ESI $\dagger$ ). The $\mathrm{C}, \mathrm{H}$, and $\mathrm{N}$ results were found to be consistent with the theoretical composition within $4 \%$, and the discrepancy in the $\mathrm{H}$ percentage might be due to the uncertainty in quantifying the hybrids water content. Scheme 1 shows the idealized synthesis steps of the POMs-based IL hybrid gel electrolytes.

The functional groups of PyPs and the hybrid POMs-ILs were further proven by NMR analyses (Fig. 1). ${ }^{1} \mathrm{H}$ NMR results show the chemical shift (ppm) values corresponding to the structure PyPs: 2.46 (p, 2H), $2.98(\mathrm{t}, 2 \mathrm{H}), 4.77(\mathrm{t}, 2 \mathrm{H}), 8.08(\mathrm{t}, 2 \mathrm{H}), 8.56(\mathrm{t}$, $1 \mathrm{H}), 8.88$ (d, 2H); PyPs- ${ }_{3}$ PWMo: 2.47 (s, 2H), 2.98 (m, 3H), 4.81 (s, 1H), 8.13 (d, 2H), 8.60 (s, 1H), 8.89 (s, 2H); PyPs- ${ }_{4} \mathrm{PMoV}$ :
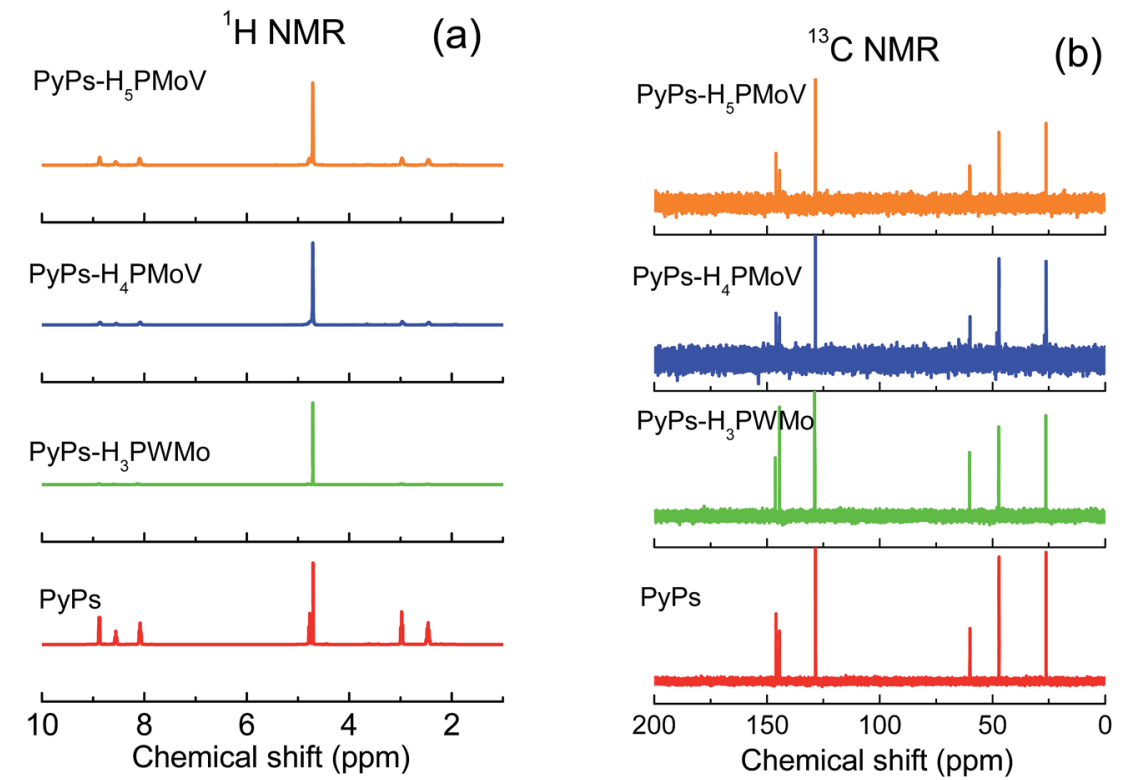

Fig. 1 (a) ${ }^{1} \mathrm{H}$ NMR and (b) ${ }^{13} \mathrm{C}$ NMR of PyPs, PyPs $-\mathrm{H}_{3}$ PWMo, PyPs $-\mathrm{H}_{4} \mathrm{PMoV}$, and PyPs $-\mathrm{H}_{5} \mathrm{PMoV}$. The chemical shift values are represented against TMS dissolved in $\mathrm{D}_{2} \mathrm{O}$. 
$2.44(\mathrm{~m}, 2 \mathrm{H}), 2.96(\mathrm{t}, 2 \mathrm{H}), 4.76(\mathrm{~s}, 1 \mathrm{H}), 8.08(\mathrm{~s}, 2 \mathrm{H}), 8.55(\mathrm{~s}, 1 \mathrm{H})$, $8.86(\mathrm{~d}, 2 \mathrm{H})$; and PyPs-H${ }_{5} \mathrm{PMoV}: 2.45(\mathrm{~m}, 2 \mathrm{H}), 2.96(\mathrm{t}, 2 \mathrm{H}), 4.77$ $(\mathrm{s}, 1 \mathrm{H}), 8.08(\mathrm{~s}, 2 \mathrm{H}), 8.55(\mathrm{~s}, 1 \mathrm{H}), 8.87(\mathrm{~d}, 2 \mathrm{H})$. The corresponding ${ }^{13} \mathrm{C}$ NMR chemical shift (ppm) results are also consistent with the ${ }^{1} \mathrm{H}$ NMR results. The ${ }^{13} \mathrm{C}$ NMR chemical shift values are for PyPs: 26.20, 47.12, 59.98, 128.48, 144.47, 145.99; PyPs$\mathrm{H}_{3}$ PWMo: 26.33, 47.22, 60.14, 128.79, 144.42, 146.26; PyPs$\mathrm{H}_{4}$ PMoV: $26.19,47.09$, 59.96, 128.50, 144.42, 146.01; and PyPs$\mathrm{H}_{5} \mathrm{PMoV}: 26.23$, 47.13, 60.01, 128.45, 144.42, 146.03. Fig. 1 summarizes the ${ }^{1} \mathrm{H}$ NMR and ${ }^{13} \mathrm{C}$ NMR results with a comparison plot of both PyPs and the hybrid IL-POMs.

\subsection{FTIR analysis}

The FTIR spectra were used to identify structural and bonding changes in the polyoxoanion units present in POM-based materials. Fig. 2 presents the FTIR spectra of the hybrids PyPs-

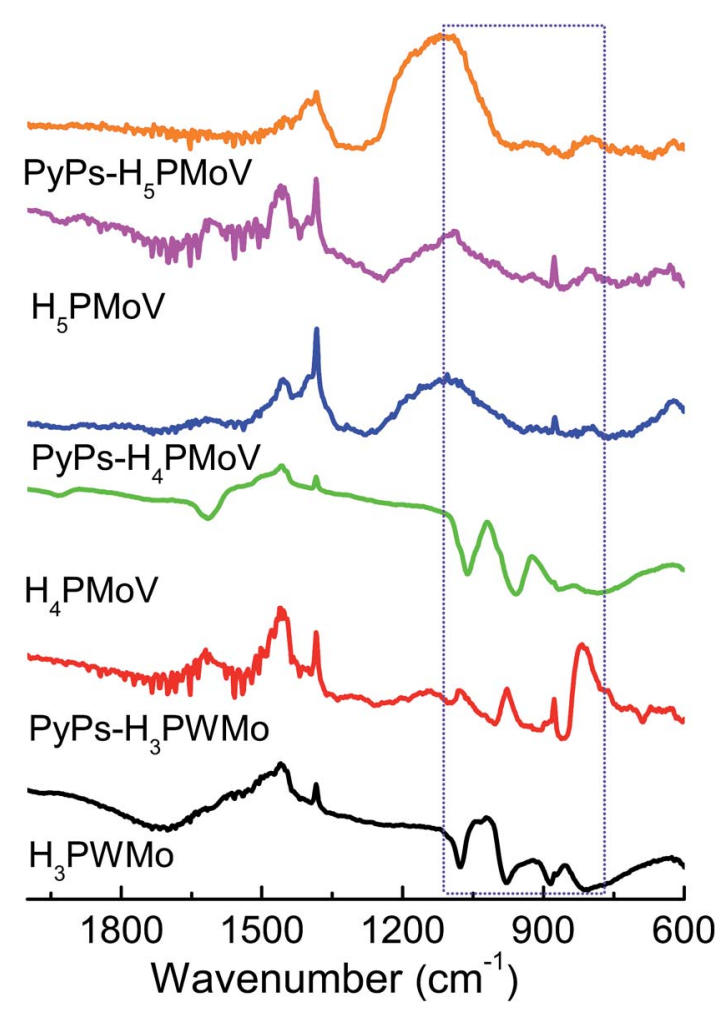

Fig. 2 FTIR spectra of heteropoly acids $\mathrm{H}_{3} \mathrm{PW}_{11} \mathrm{MoO}_{40}\left(\mathrm{H}_{3} \mathrm{PWMO}\right)$, $\mathrm{H}_{4} \mathrm{PMO}_{11} \mathrm{VO}_{40}\left(\mathrm{H}_{4} \mathrm{PMOV}\right)$ and $\mathrm{H}_{5} \mathrm{PMO}_{10} \mathrm{~V}_{2} \mathrm{O}_{40}\left(\mathrm{H}_{5} \mathrm{PMOV}\right)$ and their ILhybrids PyPs $-\mathrm{H}_{3} \mathrm{PWMO}$, PyPs $-\mathrm{H}_{4} \mathrm{PMOV}$, and PyPs $-\mathrm{H}_{5} \mathrm{PMoV}$.
$\mathrm{H}_{3} \mathrm{PWMo}$, PyPs- $\mathrm{H}_{4} \mathrm{PMoV}$ and PyPs- $\mathrm{H}_{5} \mathrm{PMoV}$ and their solid acid precursors. In the FTIR spectra, there are four characteristic vibrational bands resulting from the $\alpha$-Keggin-type heteropolyanion (for e.g., $\mathrm{PM}_{12} \mathrm{O}_{40}{ }^{3-}$ where $\mathrm{M}=\mathrm{W}, \mathrm{Mo}, \mathrm{V}$ ), $\nu\left(\mathrm{P}-\mathrm{O}_{\mathrm{a}}\right.$ ), $\nu\left(\mathrm{M}-\mathrm{O}_{\mathrm{d}}\right), \nu\left(\mathrm{M}-\mathrm{O}_{\mathrm{b}}-\mathrm{M}\right)$, and $\nu\left(\mathrm{M}-\mathrm{O}_{\mathrm{c}}-\mathrm{M}\right)$ appearing in the region between 700 and $1100 \mathrm{~cm}^{-1}\left(\mathrm{O}_{\mathrm{d}}\right.$-terminal oxygen, $\mathrm{O}_{\mathrm{b}}$-bridged oxygen of two octahedral sharing a corner, and $\mathrm{O}_{\mathrm{c}}$-bridged oxygen of two octahedrals sharing an edge). The FTIR spectra of POMILs were found to be identical to that of corresponding pristine solid acids, which also showed splitting of the $\mathrm{P}-\mathrm{O}_{\mathrm{a}}$ stretching, $\mathrm{M}-\mathrm{O}_{\mathrm{d}}$ stretching, stretching of $\mathrm{M}-\mathrm{O}_{\mathrm{b}}-\mathrm{M}$ inter bridges between corner-sharing $\mathrm{MO}_{6}$ octahedral and stretching of $\mathrm{M}-\mathrm{O}_{\mathrm{c}}-\mathrm{M}$ intra bridges between the edge-sharing $\mathrm{MO}_{6}$ octahedral. In the IR spectra of the hybrid materials, those four well-known characteristic bands prove the presence of the core HPA clusters. The decrease in electrostatic anion-anion interactions leads to an increase in the stretching and bending vibrational frequencies. For heteropoly acid $\mathrm{H}_{3} \mathrm{PW}_{11} \mathrm{MoO}_{40}$ and its hybrid material PyPs$\mathrm{H}_{3}$ PWMo, $\mathrm{M}-\mathrm{O}_{\mathrm{b}}-\mathrm{M}$ and $\mathrm{M}-\mathrm{O}_{\mathrm{c}}-\mathrm{M}$ asymmetrical stretching vibration were blue-shifted, and the wavenumber increased from 887 and 820 for $\mathrm{H}_{3} \mathrm{PW}_{11} \mathrm{MoO}_{40}$ to 914 and $855 \mathrm{~cm}^{-1}$ for PyPs$\mathrm{H}_{3}$ PWMo. There are also three characteristic peaks at 1221, 1185 $\mathrm{cm}^{-1}(\mathrm{~S}=\mathrm{O})$ and $1491 \mathrm{~cm}^{-1}$ (pyridine ring), indicating that $[\alpha-$ $\left.\mathrm{PW}_{11} \mathrm{MoO}_{40}\right]^{3-}$ had been successfully immobilized on the ionic liquid (PyPs)-modified compound. ${ }^{17} \mathrm{~A}$ table summarizing the major vibration bands is given in Table 1 .

\subsection{Powder XRD phase analysis}

Fig. 3a shows the PXRD patterns of POM-ILs and their pristine solid acids, which reveal their crystalline and amorphous states. The Keggin-type of the polyoxoanions exhibited typical peaks in the range of $2 \theta=7-11^{\circ}$ in the X-ray diffraction (XRD) pattern. ${ }^{31}$ These peaks in this range were also observed in the XRD patterns for all three hybrid materials. From these observations, it is clear that the hybrid materials were successfully prepared. However, the XRD peaks of the POM-ILs were significantly different from that of the pristine acids. The PyPs-POM hybrids had two broad diffraction peaks at $2 \theta=7-10^{\circ}$ and $15-40^{\circ}$, which showed a smectic phase that was consistent with the liquid-state crystalline nature of the samples. ${ }^{32}$ Fig. S2a (see ESI $\dagger$ ) presents the HTXRD patterns of the PyPs- $\mathrm{H}_{3}$ PWMo at different temperatures. This shows the inter-planar spacing $d(\AA)$ of the $\mathrm{IL}-\mathrm{PMo}_{11} \mathrm{~V}$ at $2 \theta \approx 9^{\circ}$ versus temperature. The $d$ value was almost stable from room temperature to $70{ }^{\circ} \mathrm{C}$. Upon increasing the temperature above $70{ }^{\circ} \mathrm{C}$, the absorbed

Table 1 FTIR Bands of IL $-\mathrm{H}_{3} \mathrm{PWMO}, \mathrm{IL}-\mathrm{H}_{4} \mathrm{PMOV}$ and IL- $\mathrm{H}_{5} \mathrm{PMOV}$ and their precursors

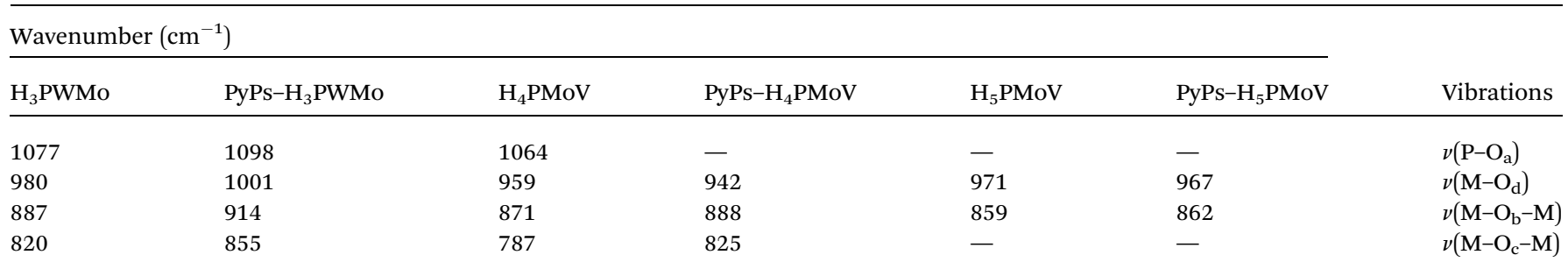




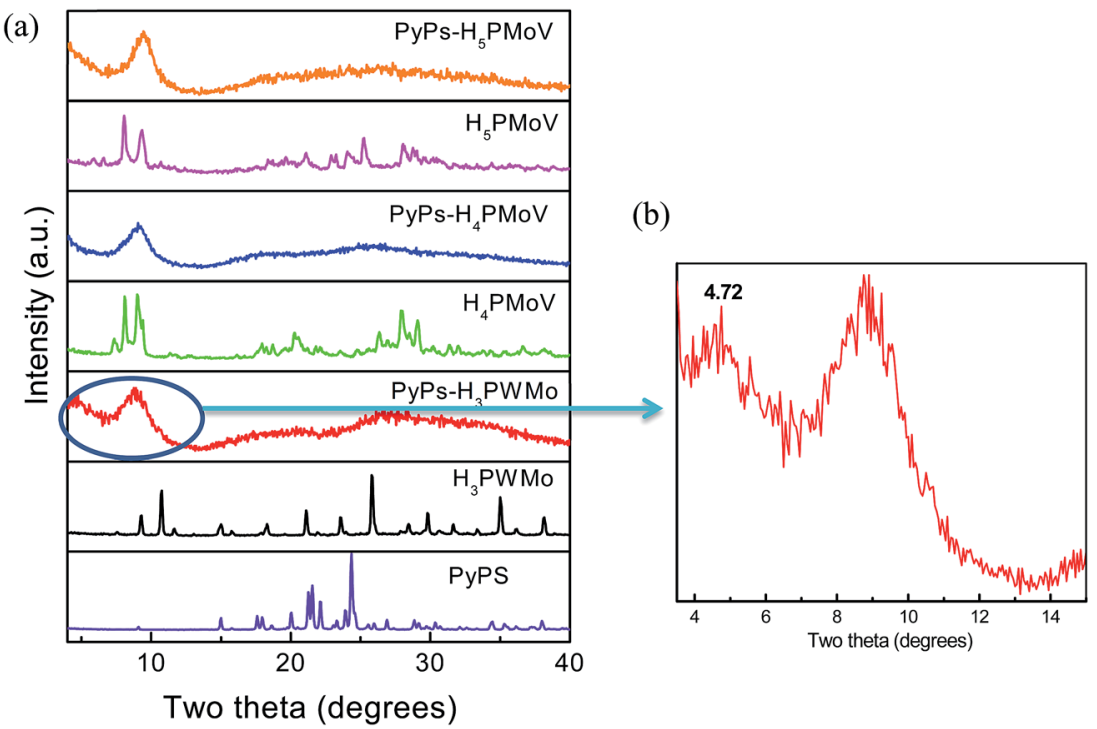

Fig. 3 PXRD patterns of (a) PyPs, heteropoly acids $\mathrm{H}_{3} \mathrm{PW}_{11} \mathrm{MoO}_{40}\left(\mathrm{H}_{3} \mathrm{PWMO}\right), \mathrm{H}_{4} \mathrm{PMO}_{11} \mathrm{VO}_{40}\left(\mathrm{H}_{4} \mathrm{PMOV}\right)$ and $\mathrm{H}_{5} \mathrm{PMO}_{10} \mathrm{~V}_{2} \mathrm{O}_{40}\left(\mathrm{H}_{5} \mathrm{PMoV}\right)$ and their PyPs-POM hybrids (PyPs- $\mathrm{H}_{3} \mathrm{PWMO}$, PyPs $-\mathrm{H}_{4} \mathrm{PMOV}$, and PyPs $-\mathrm{H}_{5} \mathrm{PMOV}$ ) and (b) PyPs- $\mathrm{H}_{3} \mathrm{PWMo}$ in the small angle region.
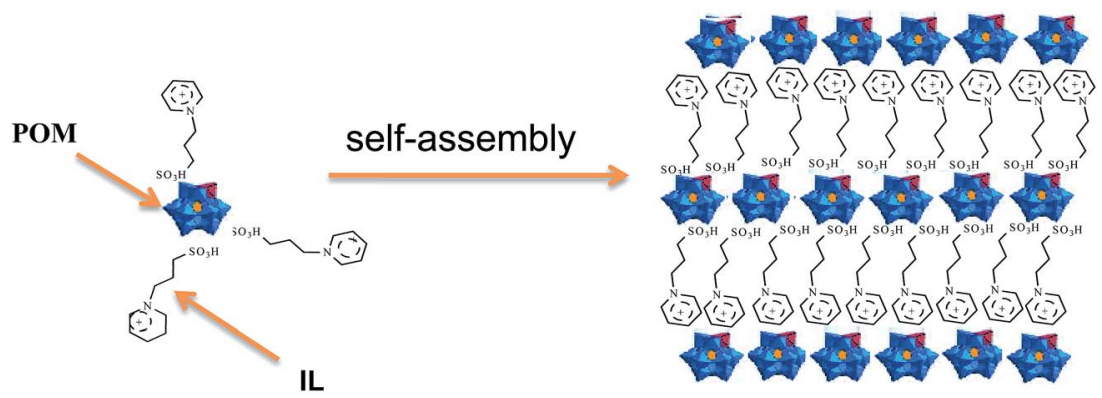

Fig. 4 The schematic illustration of the crystal structure of the POM-IL hybrid gel electrolyte.

water loss appeared to be responsible for the decreased interplanar $d$ value. A similar trend was observed for PyPs$\mathrm{H}_{4} \mathrm{PMoV}$ hybrid and is shown in Fig. S2b (see the ESI $\dagger$ ). Fig. 3b presents the PXRD pattern of PyPs- $\mathrm{H}_{3} \mathrm{PWMo}$ in the small angle region. Even though the intensities of peaks at $2 \theta=3-5^{\circ}$ were much weaker than the peak at $2 \theta \approx 9^{\circ}$, they still could be observed. The diffraction patterns contain the fundamental reflection in the small-angle region, which may be due to the regular arrangement of molecules in layers. ${ }^{22} \mathrm{As}$ a result, we can speculate that at first the molecules are organized into spheroidal aggregates, which have a core-shell structure, where each polyoxoanion is surrounded by PyPs cations due to electrostatic interactions between polyoxoanion and PyPs cation. Subsequently, IL-polyoxoanion aggregates may be regularly arranged in layers through the organic IL moieties. The schematic of the idealized crystal structure of the POM-IL hybrid gel electrolyte is shown in Fig. 4.

\subsection{Thermal analysis}

Fig. 5 shows the TGA of the HPAs and their derivative hybrid materials (POMs-IL). As expected, there was significant weight loss observed for the IL-hybrids compared to the corresponding HPAs. $\mathrm{H}_{4} \mathrm{PMoV}$ and its IL derivative (PyPs- $\mathrm{H}_{4} \mathrm{PMoV}$ ) showed the initial low temperature weight loss of $3.8 \mathrm{wt} \%$ for $\mathrm{H}_{4} \mathrm{PMoV}$ and $3.4 \mathrm{wt} \%$ for PyPs- $\mathrm{H}_{4} \mathrm{PMoV}$ due to 4 and 5 moles of water, respectively. For the PyPs- $\mathrm{H}_{4} \mathrm{PMoV}$ salt, the weight loss beginning at $250{ }^{\circ} \mathrm{C}$ is primarily due to the decomposition of PyPs organic moieties, indicating that the material is stable below $250^{\circ} \mathrm{C}$. The huge weight loss of PyPs- $\mathrm{H}_{4} \mathrm{PMoV}$ was nearly $27 \%$ and occurred between $250^{\circ} \mathrm{C}$ and $650^{\circ} \mathrm{C}$ and corresponds to the proportion of PyPs contained in the PyPs- $\mathrm{H}_{4} \mathrm{PMoV}$ (30 wt\%). The TGA of PyPs, which is provided as an inset, also shows the decomposition after $250{ }^{\circ} \mathrm{C}$. The TGA curves showed the presence of water in the ILPOMs hybrid samples; hence, the potential uptake of water might have occurred during the sample preparation, which is consistent with the result of $\mathrm{C}, \mathrm{H}$, and $\mathrm{N}$ elemental analysis. Similar observation was found for $\mathrm{H}_{3} \mathrm{PWMo}$ and its hybrid with lower weight loss as compared to that of $\mathrm{H}_{4} \mathrm{PMoV}$.

\subsection{Electrical properties}

Fig. 6 shows typical impedance spectra for the PyPs-POM hybrid, PyPs $-\mathrm{H}_{3} \mathrm{PWMo}$ at different temperatures in air (more 


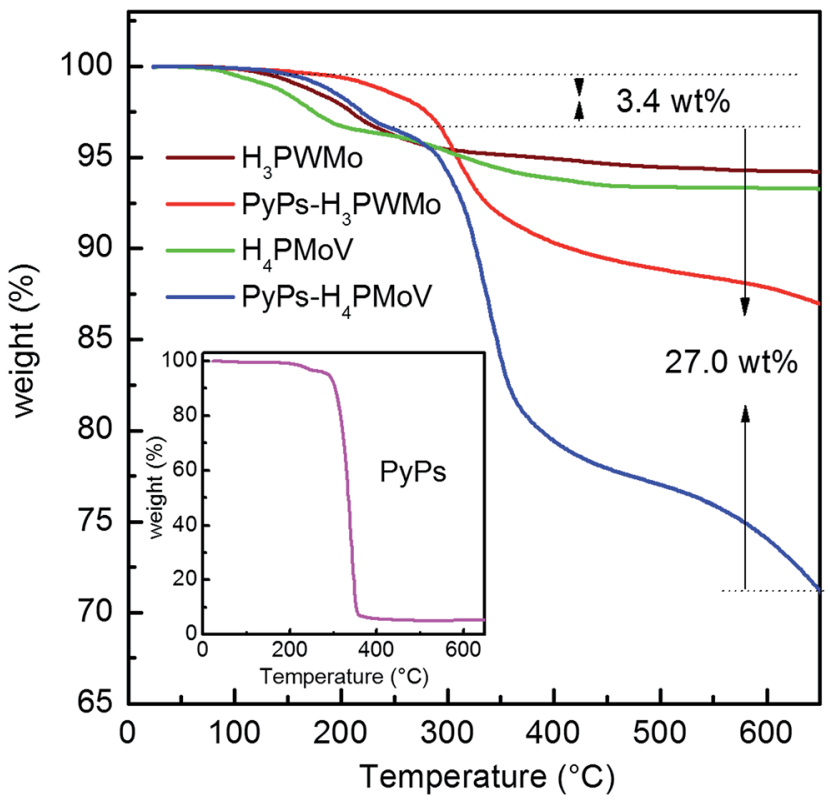

Fig. 5 The TGA of heteropoly acids $\mathrm{H}_{3} \mathrm{PW}_{11} \mathrm{MoO}_{40}\left(\mathrm{H}_{3} \mathrm{PWMO}\right)$ and $\mathrm{H}_{4} \mathrm{PMO}_{11} \mathrm{VO}_{40}\left(\mathrm{H}_{4} \mathrm{PMOV}\right)$, their PyPs-POM hybrids PyPs- $\mathrm{H}_{3} \mathrm{PWMO}$, and PyPs $-\mathrm{H}_{4} \mathrm{PMOV}$ and PyPs, which is shown in the inset.

impedance spectra of all the hybrids and the fitting results are provided in the ESI Fig. S3 and Table S2 $\dagger$ ). The resistance was found to decrease with the increase in temperature in all the cases. The conductivity, estimated from the low-frequency intercept to real axis, of the materials were calculated to be $\sim 0.1,0.01$ and $0.0003 \mathrm{Scm}^{-1}$ for PyPs- $\mathrm{H}_{3} \mathrm{PWMo}$, PyPs- $\mathrm{H}_{4} \mathrm{PMoV}$, and PyPs- $\mathrm{H}_{5} \mathrm{PMoV}$, respectively, at around $90{ }^{\circ} \mathrm{C}$. The Arrhenius plots for the bulk conductivity $(\sigma)$ of PyPs-POM hybrids are presented in Fig. 7 and were determined according to eqn (2):

$$
\sigma T=A \exp \left(\frac{-E_{a}}{k T}\right)
$$

where $T$ is the temperature, $A$ is the pre-exponential factor, $E_{\mathrm{a}}$ is the activation energy and $k$ is Boltzmann's constant. The conductivity of hybrid materials increased with increasing temperature. The conductivity sequence of the hybrid materials was in the ascending order i.e., $[\mathrm{PyPs}]_{5} \mathrm{PMo}_{10} \mathrm{~V}_{2} \mathrm{O}_{40}<[\mathrm{PyPs}]_{4}{ }^{-}$ $\mathrm{PMo}_{11} \mathrm{VO}_{40}<[\mathrm{PyPs}]_{3} \mathrm{PW}_{11} \mathrm{MoO}_{40}$. It has been suggested that larger radius of $\mathrm{W}^{6+}$ increases the molecular volume of [PyPs $]_{3} \mathrm{PW}_{11} \mathrm{MoO}_{40}$ compared to corresponding $\mathrm{V}$ based hybrids such as $[\mathrm{PyPs}]_{4} \mathrm{PMo}_{11} \mathrm{VO}_{40}$ and $[\mathrm{PyPs}]_{5} \mathrm{PMo}_{10} \mathrm{~V}_{2} \mathrm{O}_{40} \cdot{ }^{26}$ The lattice potential energy $\left(U_{\mathrm{POT}}\right)$ and molecular volume $\left(V_{\mathrm{m}}\right)$ are related, i.e., (eqn (3)): $:^{33}$

$$
U_{\mathrm{POT}} / \mathrm{kJ} \mathrm{mol}^{-1}=2\left(\frac{117.3}{V_{\mathrm{m}}^{1 / 3}}+51.9\right)
$$

The coulombic interaction between counter ions in the former case is lower than that in latter case, which resulted in higher conductivity for $\mathrm{W}$ containing $\mathrm{PyPs}-\mathrm{H}_{3} \mathrm{PWMo}$ than that of $\mathrm{V}$ containing PyPs- $\mathrm{H}_{4} \mathrm{PMoV}$, and $\mathrm{PyPs}-\mathrm{H}_{5} \mathrm{PMoV}$. However, in the case of $N$-methyl imidazolium-1-(3-sulfonic group) propyl
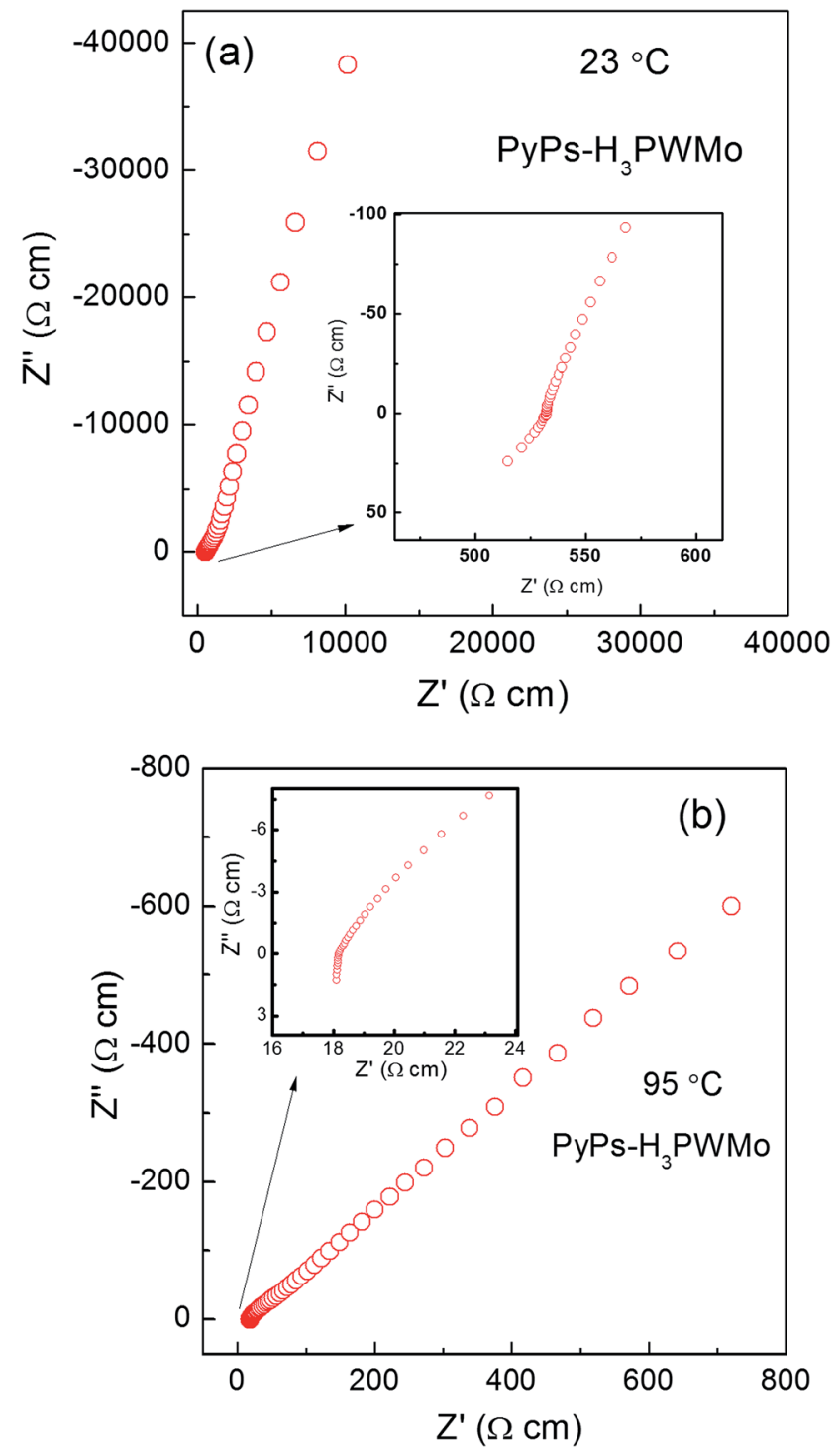

Fig. 6 Typical ac impedance spectra of PyPs-POM hybrid, PyPs$\mathrm{H}_{3} \mathrm{PWMo}$ at (a) $23{ }^{\circ} \mathrm{C}$, and (b) $95^{\circ} \mathrm{C}$ measured in an air atmosphere. Impedance plots zoomed in the high frequency side is shown in the inset for clarity.

(MIMPS) IL based hybrids, an increased conductivity was observed with $\mathrm{H}_{4} \mathrm{PMoV}$ compared to that of $\mathrm{H}_{3} \mathrm{PWMo.}{ }^{22}$ This could be due to the variation in the ILs structure. The activation energy was found to be $0.45,0.73$ and $1.16 \mathrm{eV}$ for [PyPs $]_{3} \mathrm{PW}_{11^{-}}$ $\mathrm{MoO}_{40},[\mathrm{PyPs}]_{4} \mathrm{PMO}_{11} \mathrm{VO}_{40}$ and $[\mathrm{PyPs}]_{5} \mathrm{PMo}_{10} \mathrm{~V}_{2} \mathrm{O}_{40}$, respectively, in the investigated temperature range and it was found to be consistent with the observed trend for conductivity of the hybrid materials. Based on the higher activation energy $(>0.20 \mathrm{eV})$, it can be assumed that the proton conduction in these types of hybrids appears to be following a vehicle mechanism..$^{34}$ Cyclic voltammetry analysis was used to understand the electrochemical stability window (ESW) of PyPs- $\mathrm{H}_{3}$ PWMo at room temperature, and is shown along with electrical conductivity comparison of currently studied hybrids with other known promising proton conductors including $\mathrm{Nafion}^{22,35,36}$ (Fig. 8). 


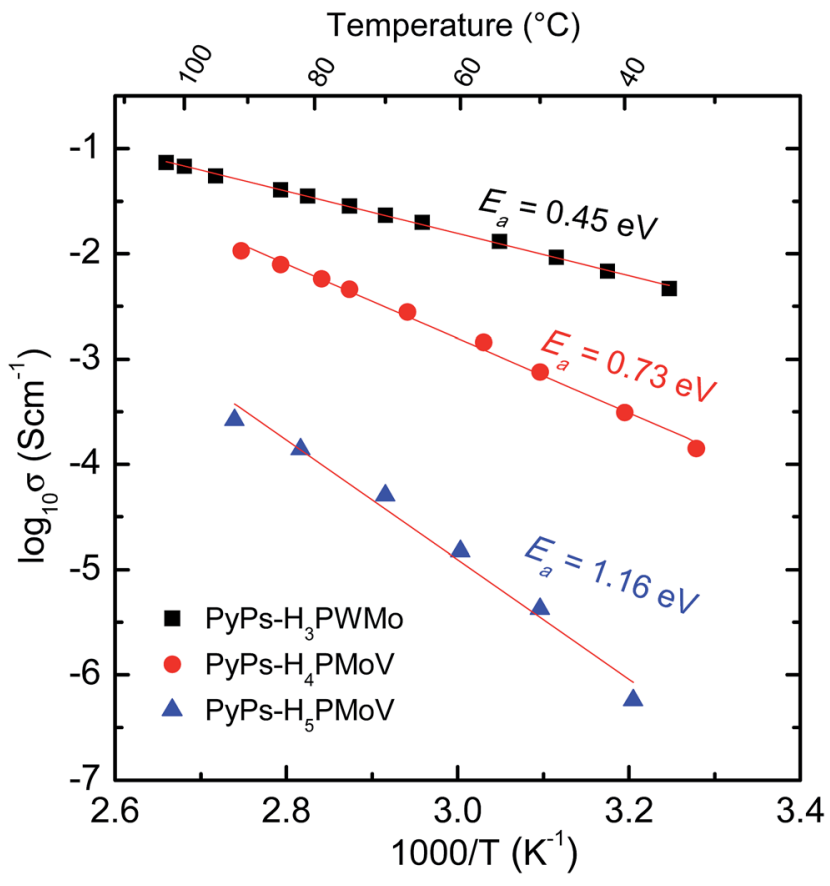

Fig. 7 Arrhenius plots for ionic conductivity for PyPs-POM gel electrolytes PyPs $-\mathrm{H}_{3} \mathrm{PWMO}$, PyPs $-\mathrm{H}_{4} \mathrm{PMOV}$, and PyPs $-\mathrm{H}_{5} \mathrm{PMOV}$.

The scanning was done at $10 \mathrm{mV} \mathrm{s}^{-1}$ between -4 and $+4 \mathrm{~V}$ using a 3-electrode set up employing $\mathrm{Pt}$ and $\mathrm{Ag} / \mathrm{AgCl}$ electrodes. The hybrid gel seemed to show a $\sim 3 \mathrm{~V} \mathrm{ESW}$, which is comparable to other IL-POM hybrids reported in the literature. ${ }^{22,37}$

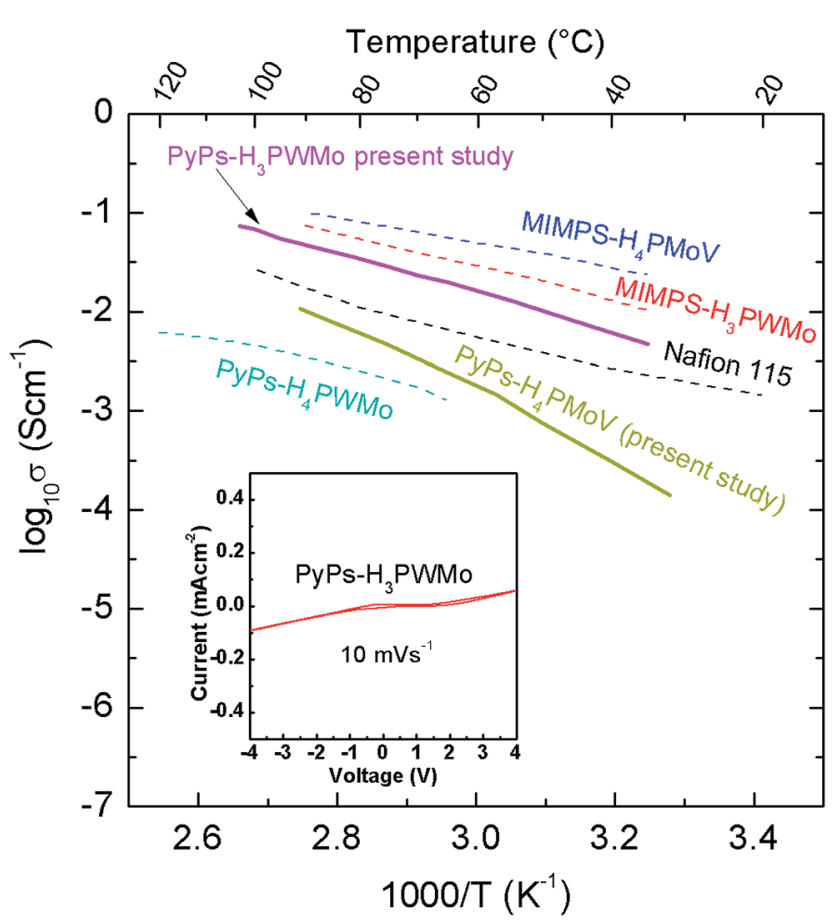

Fig. 8 Cyclic voltammetry of the PyPs $-\mathrm{H}_{3} \mathrm{PWMo}$ hybrid gel electrolyte at room temperature between -4 to $+4 \mathrm{~V} v \mathrm{v}$. $\mathrm{Ag} / \mathrm{AgCl}$ with a $10 \mathrm{mV} \mathrm{s}^{-1}$ scan rate (inset) and comparison of electrical conductivity of PyPs$\mathrm{H}_{3} \mathrm{PWMo}$ with other known promising proton conductors. ${ }^{16,29,30}$

\section{Conclusions}

In summary, we successfully synthesized three POMs-based ionic liquid (IL) gels by adjusting the packing efficiency of the ions through introducing the ILs into polyoxoanions (POMs). IR spectra and XRD patterns confirmed interaction between the organic cation and inorganic heteropoly anion in the materials. The basic Keggin structure still remained in the hybrid materials, and TG analysis demonstrated that this kind of material is thermally stable up to $\sim 250^{\circ} \mathrm{C}$. Bulk ionic conductivity values of $0.1,0.01$ and $0.0003 \mathrm{~S} \mathrm{~cm}^{-1}$ at $\sim 90{ }^{\circ} \mathrm{C}$ were obtained for $[\mathrm{PyPs}]_{3} \mathrm{PW}_{11} \mathrm{MoO}_{40},[\mathrm{PyPs}]_{4} \mathrm{PMo}_{11} \mathrm{VO}_{40}$ and $[\mathrm{PyPs}]_{5} \mathrm{PMo}_{10} \mathrm{~V}_{2} \mathrm{O}_{40}$, with activation energies of $0.45,0.73$ and $1.16 \mathrm{eV}$, respectively. Because of the promising electrochemical properties, these gellike HPA and IL derived hybrid electrolytes have potential applications in electrochemical devices such as proton exchange membrane fuel cells.

\section{Acknowledgements}

This research was supported through Discovery Grants from the Natural Science and Engineering Research Council of Canada (NSERC) (Grant Number: RGPIN-2016-03853). We thank NSERC for funding through the Research Tools and Instruments and Infrastructure grants (RTI) (cat. 1) and the Canada Foundation for Innovation (CFI) for financial support. We thank Shahrukh Shamim for his help with experimental work. We also would like to thank Dr Todd Sutherland for providing access to the FTIR instrument and Jian Li for all his help with CHN, and NMR analysis.

\section{References}

1 J. Liang, Z. Fan, S. Chen, S. Ding and G. Yang, Chem. Mater., 2014, 26, 4354-4360.

2 M.-H. Sun, S.-Z. Huang, L.-H. Chen, Y. Li, X.-Y. Yang, Z.-Y. Yuan and B.-L. Su, Chem. Soc. Rev., 2016, 45, 3479-3563.

3 Y. Li, Z.-Y. Fu and B.-L. Su, Adv. Funct. Mater., 2012, 22, 46344667.

4 Z. Huang, Z. Zhang, X. Qi, X. Ren, G. Xu, P. Wan, X. Sun and H. Zhang, Nanoscale, 2016, 8, 13273-13279.

5 H. Zhang, Y. Li, G. Zhang, T. Xu, P. Wan and X. Sun, J. Mater. Chem. A, 2015, 3, 6306-6310.

6 J. Hou, Y. Kuang, H. Shen, H. Cao, L. Luo, J. Liu, P. Wan, B. Chen, X. Sun and T. Tan, RSC Adv., 2014, 4, 11136.

7 F. M. Toma, A. Sartorel, M. Iurlo, M. Carraro, P. Parisse, C. Maccato, S. Rapino, B. R. Gonzalez, H. Amenitsch, T. Da Ros, L. Casalis, A. Goldoni, M. Marcaccio, G. Scorrano, G. Scoles, F. Paolucci, M. Prato and M. Bonchio, Nat. Chem., 2010, 2, 826-831.

8 D. Mercier, S. Boujday, C. Annabi, R. Villanneau, C.-M. Pradier and A. Proust, J. Phys. Chem. C, 2012, 116, 13217-13224.

9 S.-Y. Lee, A. Ogawa, M. Kanno, H. Nakamoto, T. Yasuda and M. Watanabe, J. Am. Chem. Soc., 2010, 132, 9764-9773. 
10 S. Murugesan, A. Akkineni, B. P. Chou, M. S. Glaz, D. A. Vanden Bout and K. J. Stevenson, ACS Nano, 2013, 7, 8199-8205.

11 P. M. Bayley, G. H. Lane, N. M. Rocher, B. R. Clare, A. S. Best, D. R. MacFarlane and M. Forsyth, Phys. Chem. Chem. Phys., 2009, 11, 7202-7208.

12 A. P. Abbott and K. J. McKenzie, Phys. Chem. Chem. Phys., 2006, 8, 4265-4279.

13 P. Gómez-Romero, K. Cuentas-Gallegos, M. Lira-Cantú and N. Casañ-Pastor, J. Mater. Sci., 2005, 40, 1423-1428.

14 A. Noda, K. Hayamizu and M. Watanabe, J. Phys. Chem. B, 2001, 105, 4603-4610.

15 J. Le Bideau, L. Viau and A. Vioux, Chem. Soc. Rev., 2011, 40, 907-925.

16 H. Xing, C. Liao, Q. Yang, G. M. Veith, B. Guo, X.-G. Sun, Q. Ren, Y.-S. Hu and S. Dai, Angew. Chem., Int. Ed., 2014, 53, 2099-2103.

17 X. Wu, X. Tong, Q. Wu, H. Ding and W. Yan, J. Mater. Chem. A, 2014, 2, 5780-5784.

18 T. Huang, N. Tian, Q. Wu and W. Yan, Soft Matter, 2015, 11, 4481-4486.

19 T. Huang, Z. Xie, Q. Wu and W. Yan, J. Alloys Compd., 2016, 660, 17-22.

20 Y. Li, X. Wu, Q. Wu, H. Ding and W. Yan, Ind. Eng. Chem. Res., 2014, 53, 12920-12926.

21 T. Huang, Z. Xie, Q. Wu and W. Yan, Dalton Trans., 2016, 45, 3958-3963.

22 X. Tong and V. Thangadurai, J. Phys. Chem. C, 2015, 119, 7621-7630.

23 X. Wu, Y. Li, Q. Wu, H. Ding and W. Yan, Phys. Chem. Chem. Phys., 2014, 16, 24598-24603.
24 Y. Leng, J. Wang, D. Zhu, X. Ren, H. Ge and L. Shen, Angew. Chem., 2009, 121, 174-177.

25 J. Xu, H. Zhang, Y. Zhao, Z. Yang, B. Yu, H. Xu and Z. Liu, Green Chem., 2014, 16, 4931-4935.

$26 \mathrm{X}$. Wu, T. Huang, X. Tong, Z. Xie, W. Chen, Q. Wu and W. Yan, RSC Adv., 2015, 5, 21973-21977.

27 S. Murugesan, O. A. Quintero, B. P. Chou, P. Xiao, K. Park, J. W. Hall, R. A. Jones, G. Henkelman, J. B. Goodenough and K. J. Stevenson, J. Mater. Chem. A, 2014, 2, 2194-2201.

28 X. Tong, N. Tian, W. Wu, W. Zhu, Q. Wu, F. Cao, W. Yan and A. B. Yaroslavtsev, J. Phys. Chem. C, 2013, 117, 3258-3263.

29 Y. Leng, J. Wang, D. Zhu, X. Ren, H. Ge and L. Shen, Angew. Chem., Int. Ed., 2009, 48, 168-171.

30 P. G. Rickert, M. R. Antonio, M. A. Firestone, K.-A. Kubatko, T. Szreder, J. F. Wishart and M. L. Dietz, J. Phys. Chem. B, 2007, 111, 4685-4692.

31 M. Rostami, A. Khosropour, V. Mirkhani, M. Moghadam, S. Tangestaninejad and I. Mohammadpoor-Baltork, Appl. Catal., A, 2011, 397, 27-34.

32 A. B. Bourlinos, K. Raman, R. Herrera, Q. Zhang, L. A. Archer and E. P. Giannelis, J. Am. Chem. Soc., 2004, 126, 1535815359.

33 J. Luo, O. Conrad and I. F. J. Vankelecom, J. Mater. Chem., 2012, 22, 20574-20579.

34 K. Checkiewicz, G. Żukowska and W. Wieczorek, Chem. Mater., 2001, 13, 379-384.

35 Y.-I. Park and M. Nagai, Solid State Ionics, 2001, 145, 149160.

36 Y. Li, X. Wu, X. Tong, Q. Wu, H. Ding and W. Yan, ECS Electrochem. Lett., 2014, 3, H9-H11.

37 J. B. Rollins and J. C. Conboy, J. Electrochem. Soc., 2009, 156, B943-B954. 